П.М. Онипченко ${ }^{1}$, О.О. Казіміров ${ }^{2}$, С.В. Атрашонок ${ }^{3}$

${ }^{1}$ Харківський національний університет Повітряних Сил ім. І. Кожедуба, Харків

${ }^{2}$ Начіональна академія Національної гвардї України, Харків

${ }^{3}$ Військова частина А-3840, Мелітополь

\title{
АНАЛІЗ ДОСВІДУ СУМІСНОГО ЗАСТОСУВАННЯ ПІЛОТОВАНОЇ ТА БЕЗПІЛОТНОЇ АВІАЦІЇ ЗБРОЙНИМИ СИЛАМИ ІНОЗЕМНИХ ДЕРЖАВ
}

У статті проведений аналіз досвіду сумісного застосування пілотованої та безпілотної авіації збройними силами іноземних держав. За поглядами іноземних військових фахівців, оптимальне сполучення пілотованої та безпілотної авіації дозволяе збільшити ефективність виконання бойових завдань, зменшити кількість втрат вартісної пілотованої авіаційної техніки та екіпажів, а також скоротити матеріальні витрати. Однак, сумісне застосування пілотованої авіації і БПЛА - це складна задача, вирішення якої можливе лише на базі високотехнологічного технічного розвитку. У ході проведеного аналізу визначена сукупність факторів, щзо визначають характер і напрямки сумісного застосування літаків $і$ БПЛА в сучасних бойових діях, наведені основні варіанти спільного застосуванні літаків і БПЛА з досвіду виконання завдань авіацією в останніх збройних конфліктах та локальних війнах, окреслені завдання, які доцільно покласти на підрозділи безпілотних літальних апаратів при їх сумісному застосуванні із частинами (підрозділами) пілотованої авіації.

Ключові слова: пілотований літальний апарат, безпілотний літальний апарат, безпілотний авіаційний комплекс, сумісне застосування, іноземна держава.

\section{Вступ}

Постановка проблеми. На даний час застосування безпілотної авіації в ЗСУ здійснюється за трьома основними способами. Перший, класичний застосування поодиноких безпілотних літальних апаратів (БПЛА). Другий - застосування БПЛА у групах. Третій - створення так званих “самостійних” авіаційних груп, що складаються з БПЛА одного або різних типів, здатних автономно виконувати широкий спектр завдань.

Поряд 3 існуючими способами застосування БПЛА також розглядається можливість створення та бойового застосування змішаних груп, що будуть включати як пілотовані так й безпілотні літальні апарати (ЛА). За поглядами іноземних військових фахівців, оптимальне сполучення пілотованої та безпілотної авіації дозволяє збільшити ефективність виконання бойових завдань, зменшити кількість втрат вартісної пілотованої авіаційної техніки та екіпажів, а також скоротити матеріальні витрати. Однак, сумісне застосування тактичної авіації i БПЛА - це складна задача, вирішення якої можливе лише на базі високотехнологічного рівня.

Аналіз останніх досліджень і публікацій. Як свідчить низка досліджень [1-4], вирішення задачі сумісного застосування пілотованої та безпілотної авіації потребує розв'язання ряду проблемних питань, таких як забезпечення стійкого управління групами БПЛА в умовах радіоелектронної протидії противника, а також створення штучного інтелекту для забезпечення автономних дій ударних БПЛА, тощо. Не менш значущими являються проблеми створення малопомітних БПЛА з бойовим потенціалом, який наближається до бойового потенціалу ударного пілотованого літака.

Концепції спільного застосування пілотованих і безпілотних систем вперше почали розробляти в армії США [5-9]. В 2007 році була здійснена перша спроба за допомогою спеціального пристрою встановити взаємодію між БПЛА і вертольотами. Враховуючи стан проблеми застосування тактичної авіації і БПЛА в найбільш передових державах [10-11], дана стаття орієнтована переважно на перспективу, ніж на вирішення конкретних задач сьогодення.

Метою статті $\epsilon$ аналіз досвіду сумісного застосування пілотованої та безпілотної авіації збройними силами іноземних держав в інтересах його реалізації в Збройних Силах України.

\section{Виклад основного матеріалу}

За поглядами іноземних військових фахівців на сумісне виконання завдань пілотованою та безпілотною авіацією впливають певні фактори, які можна поділити на наступні основні групи: організаційнотехнічні, тактико-технічні, та військово-економічні.

Сукупність факторів визначає характер і окремі риси сумісного застосування літаків і БПЛА в сучасному бою. Їх всебічний аналіз та врахування по- 
винне допомогти командирам та бойовим розрахункам пунктів управління (ПУ), що задіяні в плануванні бойового застосування авіації, розробляти пропозиції та приймати оптимальні рішення на виконання поставлених завдань.

Організаційно-технічні фактори, що впливають на сумісне виконання завдань пілотованою та безпілотною авіацією, включають: авіацією;

- організацію управління безпілотною

- характеристики систем управління БПЛА;

- ступінь автономності виконання завдань БПЛА;

- раціональний розподіл завдань між пілотованою та безпілотною авіацією;

- організацію системи ППО противника.

На сучасному етапі значний досвід в напрямку спільного застосування пілотованої й безпілотної авіації накопичений в Сухопутних військах США [6].

Екіпаж вертольоту, який має у “підпорядкуванні” БПЛА, у ході виконання бойового завдання в режимі реального часу здійснює постійний обмін даними з ним, управляє його польотом, а також засобами інформаційного забезпечення та озброєнням. Це дозволяє отримати такі переваги над противником, як більша дальність виявлення цілей, більший запас авіаційних засобів ураження, зниження ймовірності ураження вертольоту через скорочення періоду або повного виключення його перебування в зоні досяжності засобів ураження противника, зниження ефективності дій засобів ППО противника за рахунок застосування засобів радіоелектронної боротьби (РЕБ) і створення хибних цілей.

Розширення можливостей по застосуванню вертольотів і БПЛА у складі групи пов'язане з проведенням ряду організаційно-технічних заходів, до числа основних $з$ яких входять включення БПЛА в організаційно-штатну структуру авіаційних частин, проведення відповідної підготовки льотного складу (теоретична, практична, психологічна) і техніки до функціонування в єдиному складі.

Разом $з$ цим при розробці підходів до спільного застосування пілотованої й безпілотної авіації у ЗС США зіштовхнулися з рядом проблем, до основних 3 яких можна віднести наступні:

- відсутність нормативно-правової бази, що регламентує припустимі межі автономності БПЛА й робототехніки в цілому, а також відповідальність, що повинна наступати у випадку виникнення позаштатних ситуацій, що виникли 3 вини штучного інтелекту, особливо при нанесенні ударів;

- підвищені вимоги до психологічної стійкості й рівня підготовки пілота, що контролює дії відразу декількох БПЛА;

- слабке пророблення технічної складової у питаннях об'єднання різнорідних бойових систем i систем, що забезпечують.

Тактико-технічні фактори, що впливають на сумісне виконання завдань пілотованою та безпілотною авіацією, включають:

- тактико-технічні характеристики (ТTX) та бойові можливості пілотованої та безпілотної авіації;

- бойові можливості розвідувальних, вогневих та радіоелектронних засобів ППО противника;

- характеристики об'єктів дії пілотованої та безпілотної авіації ;

- бойові можливості розвідувальних, вогневих та радіоелектронних засобів ППО противника;

- можливості противника 3 розвідки та ураження місць базування частин (підрозділів) пілотованої та безпілотної авіації.

Бойові можливості безпілотної авіації визначаються тактико-технічними характеристиками літальних апаратів, рівнем підготовленості особового складу, та їхнього обладнання, у першу чергу можливостями з виявлення та ураження цілей, потрібною дальністю польоту, максимально припустимим часом знаходження в повітрі, здатністю запобігати засобам ППО противника, бойовим напруженням та наявним льотним ресурсом.

Що стосується військово-економічних факторів сумісного виконання завдань пілотованою та безпілотною авіацією то ці питання на даний час перебувають переважно в стадії досліджень [12-14]. Не вирішеними залишаються і питання взаємозв'язку військового, технічного і економічного характеру. Актуальна проблема створення малопомітних ударних БПЛА з бойовим потенціалом, прийнятним для вирішення завдань військових конфліктів середньої та великої інтенсивності, здатних діяти з пілотованими літаками в загальних бойових порядках. При цьому вартість таких БПЛА повинна бути на порядок менше вартості ударних пілотованих літаків. Це особливо важливо для масованого застосування БПЛА при вирішенні таких задач як подолання ППО противника.

Для врахування означених факторів можна виділити три основних напрямки сумісного виконання завдань пілотованою та безпілотною авіацією.

Перший напрямок пов'язаний з пошуком найбільш ефективних форм і способів застосування існуючих змішаних авіаційних формувань 3 відомим якісно-кількісним складом.

Другий напрямок пов'язаний зі створенням змішаних авіаційних формувань, здатних вирішувати поставлені завдання з найбільшою ефективністю.

Третій напрямок пов'язаний з обгрунтуванням оперативно-тактичних вимог до перспективних зразків пілотованої й безпілотної авіації.

Пошук найбільш ефективних форм і способів застосування існуючих змішаних авіаційних формувань 3 відомим якісно-кількісним складом можна 
пов’язати з пошуком найбільш раціонального розподілу функцій і завдань між пілотованою та безпілотною авіацією під час виконання поставлених завдань. Основним інструментом таких досліджень є математичне моделювання.

Дослідження зі створення змішаних авіаційних формувань, здатних вирішувати поставлені завдання 3 найбільшою ефективністю вимагають, насамперед, формулювання критерію ефективності, що враховував би не тільки ефективність рішення типових завдань, але і витрати, що пов'язані зі створенням самого авіаційного формування. Дослідження в даному напрямку здійснюються подібно до досліджень попереднього напрямку [15-16]. Розглядаються ефективність і вартість варіантів змішаних авіаційних формувань за умови їх найбільш раціонального застосування.

При обгрунтуванні оперативно-тактичних вимог до перспективних зразків пілотованої й безпілотної авіації повинні враховуватися результати моделювання ефективності і вартості змішаних авіаційних формувань, до складу яких мають входити перспективні зразки озброєнь, що досліджуються. При цьому у якості варіантів (альтернатив), що аналізуються, варто розглядати перспективні варіанти озброєння противника.

На сьогодні в ПС ЗС України відбувається перехід від застосування окремих БПЛА, переважно 3 розвідувальними функціями, для забезпечення дій пілотованої ударної авіації до масового застосування БПЛА в інтересах всіх родів авіації.

Сумісне застосування безпілотної і пілотованої авіації при існуючому рівні технологій управління та зв'язку, може базуватися лише на принципах взаємодії підрозділів безпілотної і підрозділів пілотованої авіації, що потребує детального завчасного планування бойових дій. Перехід до більш оперативних форм спільних дій, заснованих на управлінні БПЛА з боку пілотованої авіації, використанні єдиного інформаційного простору стане можливим при істотному прогресі у створенні та впровадженні авіаційних систем зв'язку та обміну інформацією стійких до впливу РЕБ, систем штучного інтелекту БПЛА.

Виходячи із цього слід очікувати, що організація спільного застосування безпілотної і пілотованої авіації в середньостроковій перспективі не буде мати принципових відмінностей від організації спільного застосування груп авіації різних родів. Планування спільного застосування безпілотної й пілотованої авіації збереже риси централізованого ієрархічного планування.

Виходячи $з$ досвіду виконання завдань авіацією в сучасних збройних конфліктах існують декілька варіантів спільного застосуванні літаків і БПЛА [1; $11 ; 17]$.
Перший. Використання БПЛА як хибних цілей для ППО противника, можливо, під час спільного бойового польоту в єдиному бойовому порядку. Реалізація способу можлива, якщо БПЛА мають швидкість польоту, що близька до швидкості польоту пілотованих ЛА (наприклад, такі як МQМ-74А “Chukar" фірми Northrop, “Рейс", “Стриж”). Цей спосіб з успіхом застосовувався в арабо-ізраїльських конфліктах.

Другий. Виконання бойового польоту при наявності спільного інформаційного поля. Розвідувальна інформація від всіх джерел інформації надається в єдиний інформаційний центр, де аналізується і надається за потребою командирам різних ланок управління. БПЛА різних класів можуть виконувати завдання, що не пов'язані безпосередньо з виконанням завдань ударної авіації, але авіація може за потребою скористатися розвідувальними даними від БПЛА. Як приклад, досить вдалим виявилося спільне застосування БПЛА RQ-1 "Predator" і літаків радіолокаційної розвідки наземних цілей Е-8 “Jstars": безпілотний літальний апарат проводив спостереження районів, схованих від Е-8 складками місцевості. Потім інформація БПЛА та Е-8 сполучалася і одночасно передавалася різним споживачам.

Третій. Розподілення завдань на різних етапах бойового польоту з узгодженням за місцем і часом. Цей варіант також передбачає наявність спільного інформаційного поля, але виконання окремих етапів польоту пілотованих ЛА за часом погоджено із завершенням або виконанням завдань БПЛА. Якщо запланований час нанесення авіаційного удару погоджено за часом з виявленням і розпізнанням цілі, то це суттєво підвищує оперативність розвідувальної інформації і ефективність виконання бойової задачі взагалі.

В якості прикладу можна згадати тактику використання БПЛА ВПС США під час війни Афганістані у 2001 р. БПЛА RQ-1 "Predator" передавали відомості про цілі (зображення) не в пункти управління і штаби, а безпосередньо екіпажам бойових літаків і вертольотів.

Четвертий варіант спільного застосуванні літаків і БПАК - підсвічування цілей променем лазера 3 борту БПЛА для забезпечення застосування кумулятивних авіаційних бомб (КАБ) або пусків протитанкових керованих ракет (ПТКР) з напівактивним лазерним наведенням (наприклад, AGM-114 "Hellfire") 3 бойових літаків або вертольотів.

В сучасних умовах для організації сумісного бойового застосування пілотованої та безпілотної авіації необхідно проаналізувати бойовий склад та можливості підпорядкованих підрозділів БПАК, рівень їх боєздатності, сильні і слабі сторони, а також їх базування.

Бойові можливості безпілотної авіації визна- 
чаються тактико-технічними характеристиками літальних апаратів та їхнього обладнання, у першу чергу, можливостями з виявлення та ураження цілей, потрібною дальністю польоту, максимально припустимим часом знаходження в повітрі, здатністю уникати впливу засобів ППО противника, бойовим напруженням та наявним льотним ресурсом, рівнем підготовленості особового складу.

Тактико-технічні характеристики сучасних БПЛА, як правило, мають наступні особливості в порівнянні з пілотованими літаками:

- невеликий діапазон наявних швидкостей та висот полоту;

- більша тривалість польоту;

- більш жорсткі обмеження по максимально припустимій швидкості вітру на зльоті і посадці;

- обмеження по дальності передавання команд управління та отримання інформації з борту;

- більша залежність від впливу засобів РЕБ противника;

- невелика номенклатура та кількість засобів ураження;

- відсутність обов'язкової прив'язки місць пуску та посадки БПЛА до стаціонарних об'єктів інфраструктури.

Виходячи 3 досвіду локальних війн та збройних конфліктів [1-2; 18], при плануванні сумісного бойового застосування пілотованої та безпілотної авіації на підрозділи БПАК доцільно покласти виконання наступних завдань:

- ведення повітряної розвідки в районах, де можливе знаходження засобів ППО противника;

- цілевказання та коригування вогню при нанесенні авіаційних ударів;

- контроль результатів вогневого ураження;

- виконання пошукових заходів в “сірій зоні” та на території противника в системі пошуковорятувального забезпечення;

- нанесення ударів по об'єктам системи ППО противника;

- створення хибних повітряних цілей для введення в оману системи протиповітряної оборони противника;

- створення керованих полів радіозавад на основі багатофункціональної простороворозподіленої системи постановки завад, що створюється 3 використанням БПЛА, та (або) передавачів завад, що закидаються;

- спостереження (моніторинг) за визначеними районами місцевості.

Основні зусилля підрозділів БПЛА доцільно зосередити на викритті, вогневому та функціональному ураженні, зменшенні бойового потенціалу засобів ППО противника.

Сумісне застосування пілотованої та безпілот- ної авіації потребує налагодженої взаємодії їх сил та засобів, що полягає у раціональному розподілі завдань та узгодженні дій підрозділів за місцем, часом та способами виконання бойових завдань.

Порядок взаємодії визначається в ході розроблення плану операції (бойових дій). Доведення завдань до взаємодіючих частин (підрозділів) полягає у виборі найбільш надійного та ефективного в умовах, що склалися способу доведення задач, організації контролю за проходженням оперативних (бойових) документів і сигналів бойового управління та правильним їх усвідомленням підлеглими. Підтримка встановленої взаємодії $є$ неодмінною умовою для досягнення цілей операції (бойових дій).

\section{Висновки}

За поглядами іноземних військових фахівців існують певні фактори, сукупність яких визначає характер і окремі риси сумісного застосування літаків і БПЛА в сучасному бою. Їх всебічний аналіз та врахування повинно допомогти командирам та бойовим розрахункам пунктів управління, що задіяні в плануванні бойового застосування авіації, розробляти пропозиції та приймати оптимальні рішення на виконання поставлених завдань.

Для організації сумісного бойового застосування пілотованої та безпілотної авіації необхідно проаналізувати бойовий склад та можливості підпорядкованих підрозділів БПАК, рівень їх боєздатності, сильні і слабі сторони, а також їх базування. Виходячи 3 цього, обирається доцільний варіант застосування літаків та БПЛА.

Аналіз досвіду збройних сил іноземних держав показав, що при сумісному застосуванні літаків i БПЛА на підрозділи БПЛА доцільно покласти виконання таких завдань як: ведення повітряної розвідки; цілевказання та коригування; контроль результатів вогневого ураження; виконання пошукових робіт; нанесення ударів по об'єктах системи ППО противника; створення хибних повітряних цілей; створення керованих полів радіозавад; спостереження (моніторинг) за визначеними районами місцевості.

Сумісне застосування пілотованої та безпілотної авіації потребує налагодженої взаємодії їх сил та засобів, яка досягається шляхом проведення комплексу заходів з боку командирів, начальників усіх рівнів, направлених на упорядкування дій підпорядкованих та взаємодіючих частин і підрозділів для створення сприятливих умов або отримання бажаного результату в операції (бойових діях).

Проаналізований досвід сумісного застосування пілотованої та безпілотної авіації збройними силами іноземних держав може бути реалізований в бойовій діяльності Збройних Сил України. 


\section{Список літератури}

1. Молоканов Г. Ф. Об эффективности применения авиации в локальных войнах. Военная мысль. 2004. № 8. URL: http://militaryarticle.ru/voennaya-mysl/2004-vm/9414-ob-jeffektivnosti-primenenija-aviacii-v-lokalnyh (дата звернення: 30.04.2021).

2. Dupuy T. Understanding War. History and Theory of Combat. 2nded. USA : Nova Publishers, 1998. 312 p.

3. Досужий В. А. Підготовка операторів безпілотних авіаційних систем до професійної діяльності: досвід США: навч.-метод. посіб. Кропивницький : ЛА НАУ, 2019. 118 с.

4. Основні тенденції створення та застосування груп безпілотних літальних апаратів / Лупандін В. А. та ін. Наука і техніка Повітряних Сил Збройних Сил Украӥни. 2019. № 2(35). С. 88-96. https://doi.org/10.30748/nitps.2019.35.11.

5. Стрельников Д. Концептуальные взгляды командования ВВС США на развитие беспилотной авиации. Зарубежное военное обозрение. 2017. № 5. С. 51-61.

6. Стрельников Д., Сидоров А., Мгимов Ю. Совместное применение пилотируемой и беспилотной авиации США в первой половине XXI века. Зарубежное военное обозрение. 2018. № 4. С. 52-59.

7. Unmanned System Integrated Roadmap FY2013-2038. U.S. Department of Defense Washington, DC, 2013.168 p. URL: https://archive.defense.gov/pubs/dod-usrm-2013.pdf (accessed 30.04.2021).

8. United States Air Force Unmanned Aircraft System Flight Plan 2009-2047. 2009. 82 p. URL: https://fas.org/irp/program/collect/uas_2009.pdf (accessed 29.04.2021).

9. The USAF Remotely Piloted Aircraft (RPA) Vector: Vision and Enabling Concepts: 2013-2038. 2014. 136 p. URL: http://www.japcc.org/wp-content/uploads/2015/03/JAPCC-RPAS-Operations-in-Contested-Environments.pdf (accessed 29.04.2021).

10. Павлушенко М., Евстафьев Г., Макаренко И. Беспилотные летательные аппараты: история, применение, угроза распостранения и перспективы развития / под ред. М. Павлушенко. Москва : Права человека, 2005. 611 с.

11. Кондратьев А. Перспективы развития и применения беспилотных и роботизированных средств вооруженной борьбы в ВС ведущих зарубежных стран. Зарубежное военное обозрение. 2011. № 5. С. 14-21.

12. Скорик А. Б., Демидов Б. А. Анализ общей методологии формирования требований к военно-техническим системам и вооружению ЗРВ. Ч. 1. Эволюционное развитие оперативно-тактических требований. Системи озброєння $i$ військова техніка. 2010. № 3(23). С. 75-81.

13. Ачасов О. Б., Буравлев А. И. Аналитическая модель оценки эффективности воздушно-космической обороны в условиях глобального удара высокоточным оружием. Вооружение и эконолика. 2014. № 2(27). С. 10-20.

14. Шамко В. Є., Жарик О. М., Коваль В. В. Розвиток форм і способів застосування Повітряних Сил Збройних Сил України в сучасних умовах ведення збройної боротьби. Наука і техніка Повітряних Сил Збройних Сил України. 2018. № 2(31). C. 9-15. https://doi.org/10.30748/nitps.2018.31.01.

15. Лазебник С. В., Малюга В. Г., Нерубацький В. О. Підхід до формування системи показників ефективності угруповань військ. Збірник наукових прачь Харківського університету Повітряних Сил. 2012. № 4(33). С. 5-8.

16. Клюшніков I. М., Нерубацький В.О., Шалигін А.А. Підхід до формування критеріального апарату оцінки ефективності змішаних угруповань пілотованої та безпілотної авіації. Наука і техніка Повітряних Сил Збройних Сил Украӥни. 2019. № 4(37). C. 50-55. https://doi.org/10.30748/nitps.2019.37.07.

17. Фещенко А. Л. Застосування безпілотних літальних апаратів у воєнних конфліктах кінця XX - початку XXI століття : автореф. дис. на здобуття наук. ступеня канд. військ. наук : 20.02.22. Київ, 2011. 20 с.

18. Кучеренко Ю. Ф., Науменко М. В., Кузнєцова М. Ю. Аналіз досвіду застосування безпілотних літальних апаратів та визначення напрямку їх подальшого розвитку при веденні мережецентричних операцій. Системи озброєння $i$ військова техніка. 2018. № 1(53). C. 25-30. https://doi.org/10.30748/soivt.2018.53.03.

Надійшла до редколегії 20.05.2021

Схвалена до друку 13.07.2021

\section{Відомості про авторів:}

Онипченко Павло Миколайович

кандидат педагогічних наук доцент професор кафедри Харківського національного університету Повітряних Сил ім. І. Кожедуба, Харків, Україна

https://orcid.org/0000-0003-4497-327X

\section{Казіміров Олександр Олексійович}

кандидат військових наук доцент доцент кафедри Національної академії

Національної гвардії України,

Харків, Україна

https://orcid.org/0000-0002-7509-5118

\section{Information about the authors:}

Pavlo Onypchenko

Candidate of Pedagogical Sciences Associate Professor Professor of Department of Ivan Kozhedub Kharkiv

National Air Force University,

Kharkiv, Ukraine

https://orcid.org/0000-0003-4497-327X

\section{Oleksandr Kazimirov}

Candidate of Military Sciences Associate Professor Senior Lecturer of Department of National Academy of the National Guard of Ukraine,

Kharkiv, Ukraine

https://orcid.org/0000-0002-7509-5118 


\section{Атрашонок Сергій Валерійович}

заступник командира бригади з льотної підготовки військова частина А-3840,

Мелітополь, Україна

https://orcid.org/0000-0002-0723-5836

\author{
Serhii Atrashonok \\ Deputy Commander of the Flight Training Brigade \\ Military Base A-3840, \\ Melitopol, Ukraine \\ https://orcid.org/0000-0002-0723-5836
}

\title{
АНАЛИЗ ОПЫТА СОВМЕСТНОГО ПРИМЕНЕНИЯ ПИЛОТИРУЕМОЙ И БЕСПИЛОТНОЙ АВИАЦИИ ВООРУЖЕННЫМ СИЛАМ ИНОСТРАННЫХ ГОСУДАРСТВ
}

\author{
П.Н. Онипченко, А.А. Казимиров, С.В. Атрашонок
}

В статье проведен анализ опыта совместного применения пилотируемой и беспилотной авиации вооруженными силами иностранных государств. По взглядам иностранных военных спечиалистов, оптимальное сочетание пилотируемой и беспилотной авиачии позволяет повысить эффективность выполнения боевых задач, уменьшить количество потерь дорогостоящей пилотируемой авиационной техники и экипажей, а также сократить материальные расходы. Однако, совместное применение пилотируемой авиации и БПЛА - это сложная задача, решение которой возможно только на основе высокотехнологического технического развития. В ходе проведенного анализа определена совокупность факторов, определяющих характер и направления совместного применения самолетов и БПЛА в современных боевых действиях, приведены основные варианты совместного применении самолетов и БПЛА из опыта выполнения задач авиацией в последних вооруженных конфликтах и локальных войнах, намечены задачи, которые целесообразно возложить на подразделения беспилотных летательных аппаратов при их совместном применении с частями (подразделениями) пилотируемой авиации.

Ключевые слова: пилотируемый летательный аппарат, беспилотный летательный аппарат, беспилотный авиаичонный комплекс, совместное применение, иностранное государство.

\section{ANALYSIS OF COMPATIBILITY EXPERIENCE MANNED AND UNMANNED AERIAL VEHICLES BY THE ARMED FORCES OF FOREIGN STATES}

\section{P. Onypchenko, O. Kazimirov, S. Atrashonok}

The article analyzes the experience of joint use of manned and unmanned aerial vehicles by the armed forces of foreign countries. According to foreign military experts, the optimal combination of manned and unmanned aerial vehicles can increase the efficiency of combat missions, reduce the number of losses of costly manned aircraft and crews, as well as reduce material costs. However, the joint use of manned aircraft and UAVs is a difficult task, the solution of which is possible only on the basis of high-tech technical development. The joint use of unmanned and manned aircraft at the current level of control and communication technologies can be based only on the principles of interaction between unmanned and unmanned aerial vehicles, which requires detailed advance planning of hostilities. The transition to more operational forms of joint actions based on UAV control by manned aircraft, the use of a single information space will be possible with significant progress in the creation and implementation of aviation communication systems and information exchange resistant to EW, UAV systems. Therefore, the use of manned and unmanned aerial vehicles requires a well-established interaction of their forces and means, which consists in the rational distribution of tasks and coordination of actions of units in place, time and methods of combat missions. Based on this, it should be expected that the organization of joint use of unmanned and manned aircraft in the medium term will not be fundamentally different from the organization of joint use of aviation groups of different types. Planning the joint use of unmanned and manned aircraft will retain the features of centralized hierarchical planning. The analysis identified a set of factors that determine the nature and direction of joint use of aircraft and UAVS in modern hostilities, the main options for joint use of aircraft and UAVS from the experience of aviation in recent armed conflicts and local wars, outlined the tasks that it is expedient to put on subdivisions of unmanned aerial vehicles at their joint application with parts (subdivisions) of manned aviation.

Keywords: manned aircraft, unmanned aerial vehicle, unmanned aerial vehicle, joint use, foreign state. 